\title{
Biochemical Characterization and Nutritional Profile of the Pulp of Saba senegalensis from Côte d'Ivoire Forest
}

\author{
DIABAGATE Hadja Mawa Fatim ${ }^{1, *}$, TRAORE Souleymane ${ }^{1}$, \\ CISSE Mohamed ${ }^{2}$, SORO Doudjo ${ }^{3}$, BROU Kouakou ${ }^{1}$ \\ ${ }^{1}$ Food Sciences and Technology Department, Laboratory of Nutrition and Food Safety, Nangui Abrogoua University, \\ Abidjan, Côte d'Ivoire \\ ${ }^{2}$ Department of Genetic Biochemistry, Peleforo Gon Coulibaly University, Korhogo, Côte d'Ivoire \\ ${ }^{3}$ Laboratory of Chemical, Food and Environmental Processes Sciences, INP-HB, Yamoussokro, Côte d'Ivoire \\ *Corresponding author: trasouley@yahoo.fr
}

Received January 03, 2019; Revised February 06, 2019; Accepted February 18, 2019

\begin{abstract}
The aim of this study was to evaluate the nutritional potential of the Saba pulp for better valorisation. The study was carried out on the fruit of Saba Senegalensis collected in the north area of Côte d'Ivoire. After the pulp extraction, the biochemical analyses were determined. Macronutrients (total carbohydrate, proteins and fat content), micronutrients (mineral and vitamin) and nutritional profile of the pulp were determined. The results showed that proteins and fat content $(2.91 \pm 0.51 \%)$ and $(1.48 \pm 0.21 \%)$ respectively were lower in the Saba pulp. On the other hand, total carbohydrate $(8.42 \pm 0.74 \%)$ and total sugar $(6.13 \pm 0.12 \%)$ were higher in this pulp. The results showed that Saba pulp was rich in potassium $(116.6 \pm 2.06 \mathrm{mg} / 100 \mathrm{~g})$, vitamin C $(36.67 \pm 2.22 \mathrm{mg} / 100 \mathrm{~g})$ and $\beta$-carotene $(189.62 \pm 1.33 \mu \mathrm{g} / 100 \mathrm{~g})$. It contains also phytonutrients such as total phenols $(264.76 \pm 4.54 \mathrm{mg} / 100 \mathrm{~g})$ and the antinutritionals factors such as phytates $(31.18 \pm 0.13 \mathrm{mg} / 100 \mathrm{~g})$. The nutrient profile by the determination of scores SAIN $>5$ and LIM $<7.5$ classified the Saba senegalensis pulp in food of group 1, recommended foods for health. Due to the high energy value, Saba fruit could be recommended as a local juice to prevent certain pathology of the malnutrition.
\end{abstract}

\section{Keywords: Saba senegalensis, pulp, nutritional values, SAIN, LIM, phytonutrients}

Cite This Article: DIABAGATE Hadja Mawa Fatim, TRAORE Souleymane, CISSE Mohamed, SORO Doudjo, and BROU Kouakou, "Biochemical Characterization and Nutritional Profile of the Pulp of Saba senegalensis from Côte d'Ivoire Forest." American Journal of Food and Nutrition, vol. 7, no. 1 (2019): 19-25. doi: 10.12691/ajfn-7-1-4.

\section{Introduction}

In the tropical countries, many wild fruits are consumed by the rural populations. These fruits contribute to improve quality of feed rations through the supply in micronutrients, but very few information are available on these local fruits concerning their annual productions, their vegetative cycles [1]. According to [2], some of these fruits, although known by the people, were less passion due to their organoleptic quality, the eating habits and especially of the ignorance of their nutritional values and therapeutic. Among these fruits species, appears Saba senegalensis which is a species of plants of the family of Apocynaceae.

Saba senegalensis is a wild liana which pushes in African savannahs. As an indigenous fruits tree, Saba senegalensis fruit is called by different language dialects. This fruit is called Saba in French, zaban in Malinké language, amani in Baoulé, wèda in Mooré, Madd in Wolof and côcôta in the urban language of Côte d'Ivoire. Saba Senegalensis is a globulous envelope which contains seeds coated with yellow pulps and juicy [3]. Data from [4] demonstrated that these orange-yellow fruit pulps and juicy are acid and sweet but are not appreciated by everyone because the acid taste similar to that of tamarind can disturb sometimes. Nutritionally, the studies carried of by [4] in Burkina Faso, reported that the fruits of Saba senegalensis are a true source of provitamin A ( $\beta$-carotene $=1559 \mu \mathrm{g} / \mathrm{g}$ ) which would play a significant role in the prevention of cancer. Moreover, [5] in Burkina Faso and [6] in Senegal revealed that Saba senegalensis are high content of antioxidants activities (17.57 mmol AEAC/100 $\mathrm{g}$ for pulp and $18.4 \mu \mathrm{g} / \mathrm{mL}$ for leaves). Previous studies stablished by [7] showed that Saba comorensis pulp was acidic $(\mathrm{pH}=3.10 \pm 0.04)$ and rich in crude protein $(4.83 \pm 0.01 \mathrm{~g} / 100 \mathrm{~g})$, dietary fibre $(7.97 \pm 0.85 \mathrm{~g} / 100 \mathrm{~g})$, and minerals like magnesium $(894.9 \pm 0.32 \mathrm{mg} / 100 \mathrm{~g})$ and calcium (209.0 $\pm 0.51 \mathrm{mg} / 100 \mathrm{~g})$ According to [8] and [9], the indigenous fruits have great opportunities to be developed into products like juice, jam and wine that can improve not only the nutrition and health of people, but also livelihoods.

In Côte d'Ivoire, the previous studies carried out by [10], [1] and [11] in the ethnobotanic field showed the use of 
leaves, roots and fruit of Saba senegalensis in human health for the treatment of certain diseases such as the dysentery, the diarrhoea and the cough. The nutritional value of Saba senegalensis pulp has not been investigated. Yet a better knowledge of the nutritional composition followed by an extension of the research results will make it possible to remedy the problems of malnutrition considerably in Côte d'Ivoire. In this study, the aim was to determine the nutritional potential of the pulp of Saba senegalensis for a better valorisation in Côte d'Ivoire.

\section{Materials and Methods}

\subsection{Materiel}

The plant material was collected from Waraniéné, area located at approximately $5 \mathrm{~km}$ of Korhogo (northern of Côte d'Ivoire) (Figure 1).

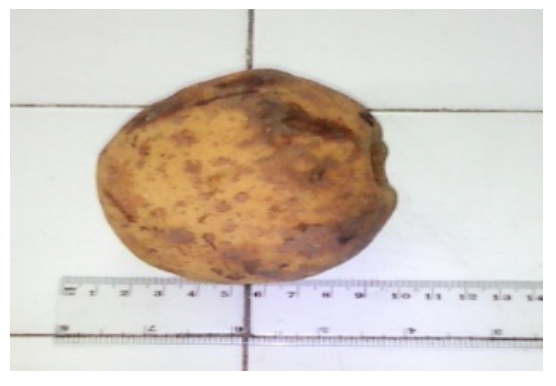

Figure 1. Fruits of Saba senegalensis

\subsection{Methods}

\subsubsection{Saba Pulp Extraction}

The Saba Senegalensis fruits (10 kg) were cutted into half with stainless steel knife. The combination of the pulp with seeds was removed with stainless spoon. The pulp together with the seeds were put into the mixer of mark ilux (NO: LX-176P/AC: 220-240V $50 \mathrm{~Hz} 350 \mathrm{~W}$ ) for mixing. The pulp together with the seeds were put into the stainless-steel sieve and blended manually to separate the seeds from the pulp. The pulps obtained was stored at $-20^{\circ} \mathrm{C}$ for the various analysis

\subsubsection{Biochemical Composition of the Saba Pulp pH Measurement}

The $\mathrm{pH}$ is determined according to the method of [12] using a pH-meter (Consort pH-meter P 107).

\section{Titratable acidity}

Titratable acidity was determined according to AOAC standard method by titrating $10 \mathrm{ml}$ of the pulps and juices against $0.1 \mathrm{M} \mathrm{NaOH}$ standard solution using phenolphthalein indicator [13].

\section{Dry matter content}

Moisture was determined by drying the sample at $105^{\circ} \mathrm{C}$ for $24 \mathrm{~h}$ according to [13]. Samples were then cooled in desiccators and weighed. The loss of weight was expressed as a percentage of the initial weights of the samples give their moisture content.

\section{Protein content}

Protein was determined by determination of total nitrogen according to the Kjeldahl method [14]. The principle: under the action of $\mathrm{NAOH}$ and after sulphuric mineralization in the presence of catalyst (CuSO4), ammoniac formed was neutralized. The ammonia in the sample solution was then distilled into the boric acid until it changed completely to bluish green. The distillate was then titrated with $0.1 \mathrm{~N} \mathrm{HCl}$ solutions until it became colourless. The percent total nitrogen and crude protein were calculated using a conversion factor of 6.25 .

\section{Fat content}

Fat was determined based on the Sohxlet extraction method of [15]. Five gram $(5.0 \mathrm{~g})$ of the sample was introduced into a cartridge of Whatman. An empty flask reweighed and containing $60 \mathrm{ml}$ of hexane was placed on the heating block of the Soxhlet apparatus and heated at $110^{\circ} \mathrm{C}$. After 6 hours of extraction, the flask was removed from apparatus and then the solvent was evaporated on a Rotary Evaporator. The flask containing the fat and residual solvent was placed on a water bath to evaporate the solvent followed by a further drying in an oven at $60^{\circ} \mathrm{C}$ for $30 \mathrm{~min}$ to completely evaporate the solvent. It was then cooled in desiccators and weighed. The fat obtained was expressed as a percentage of the initial weight of the sample.

\section{Total carbohydrate content}

Total carbohydrate content is determined by difference method $[100 \%-(\%$ moisture $+\%$ ash $+\%$ fat + protein $\%)]$.

\section{Ash content}

Ash was obtained according to [13]. A 5 g sample was weighed into a previously dried and weighed porcelain crucible. The crucible with its content was placed in a furnace at $550^{\circ} \mathrm{C}$ for $6 \mathrm{~h}$. After cooling in desiccators, the crucible with its content was weighed. The weight of the ash was expressed as a percentage of the initial weight of the sample.

\section{Mineral content}

Mineral content are determined by atomic absorption spectrophotometry. Ash (0.1g) is weighed in platinum crucibles to which was added $1 \mathrm{ml}$ of distilled water. In each crucible, $5 \mathrm{ml}$ of hydrofluoric acid $50 \%$ and 2 drops of sulfuric acid (v/v) were added. Whole, well homogenized and heated at $100^{\circ} \mathrm{C}$ until fully evaporated. Residue obtained was dissolved in $10 \mathrm{ml}$ of $50 \%$ hydrochloric acid. Solution was left to stand for 10 minutes on the bench and the final volume was brought to $100 \mathrm{ml}$.

\section{Vitamin $C$ content}

The method used for the dosage is that described by [16]. Ten (10) grams of pulp are watered in $40 \mathrm{~mL}$ of acetic metaphosphoric-acid acid $(2 \% ; \mathrm{p} / \mathrm{v})$. The mixture obtained is centrifuged with $3000 \mathrm{trs} / \mathrm{min}$ during $20 \mathrm{~min}$. The supernatant is adjusted to $50 \mathrm{ml}$ with water distilled boiled and cooled to be kept dry. A test specimen of 10 $\mathrm{mL}$ introduced into an Erlenmeyer is titrated with the 2.6 DCPIP with $0.5 \mathrm{~g} / \mathrm{L}$ until the turn with the pink persisting during 30s.

\section{Fibbers Content}

Crude fibers were proportioned according to the method described by [13]. Two (2) gram of the sample are weighed in a balloon. $50 \mathrm{~mL}$ of sulphuric acid $0.25 \mathrm{~N}$ was added to the contents was homogenized and the whole carried with boiling during $30 \mathrm{~min}$ under cooling agent with backward flow. Then, $50 \mathrm{~mL}$ of sodium $0.31 \mathrm{~N}$ are added to the contents and the whole carried to boiling 
during 30 min under cooling agent to backward flow. The extract obtained is filtered on filter paper Whatman and the residue is washed several times at hot water until complete elimination of alkalis. After elimination, the residue is dried with the drying oven with $105^{\circ} \mathrm{C}$ during 8 $\mathrm{H}$, cooled with the weighed desiccator then. The residue obtained is incinerated with the furnace with $550^{\circ} \mathrm{C}$ during $3 \mathrm{~h}$. Finally, it is cooled with the desiccator then weighed ashes.

\subsubsection{Phytonutrients}

\section{Phenolic content}

The total phenolics were estimated by the method of Folin-Ciocalteu [17]. $800 \mu \mathrm{l}$ of reagent of Folin-Ciocalteu are added to $200 \mu \mathrm{l}$ of pulp extract, then the mixture is left at ambient temperature during $2 \mathrm{~min} .1 \mathrm{ml}$ of sodium carbonate $\left(75 \mathrm{~g} .1^{-1}\right)$ was added. The reactional mixtures are agitated and incubated $15 \mathrm{~min}$ with $50^{\circ} \mathrm{C}$. The reading of the absorptance with $760 \mathrm{~nm}$ is done with help to a spectrophotometer UV 1205. The content of the phenolic compounds is calculated starting from a calibration curve.

\section{Flavonoids content}

The dosage of the flavonoïdes was carried out according to the method described by [18]. A volume of $0.5 \mathrm{ml}$ of pulp extract is introduced into a tube. At this volume, is successively added $0.5 \mathrm{ml}$ of distilled water, $0.5 \mathrm{ml}$ of aluminium chloride with $10 \%, 0.5 \mathrm{ml}$ of acetate of potassium $1 \mathrm{~N}$ and $2 \mathrm{ml}$ of distilled water. The tube is left at rest during $20 \mathrm{~min}$ with the darkness and the optical density is read to $415 \mathrm{~nm}$ against a white.

\subsubsection{Antinutritionals Factors}

The quantification of the phytates is based on the method of [19]. The optical density was read to $470 \mathrm{~nm}$ against a white.

The oxalic acid content was proportioned according to the method described by [14].

The dosage of the tannins was carried out according to the method described by [20]. One (1) $\mathrm{ml}$ of pulp extract is introduced into a test tube. To the contents of the tube 5 $\mathrm{ml}$ of reagent are added to vanillin. The tube is left at rest during 20 min with the darkness and the optical density is read to $500 \mathrm{~nm}$ against a white.

\subsubsection{Nutritional Profile}

The nutritional profile used was the SAIN and LIM system described by [21]. The SAIN refers to the favourable aspects of the food (qualifying nutrients) and the LIM refers to the unfavourable aspects (disqualifying nutrients). A food has a good profile when its SAIN is high and its LIM is low.

SAIN calculation formula is as follows:

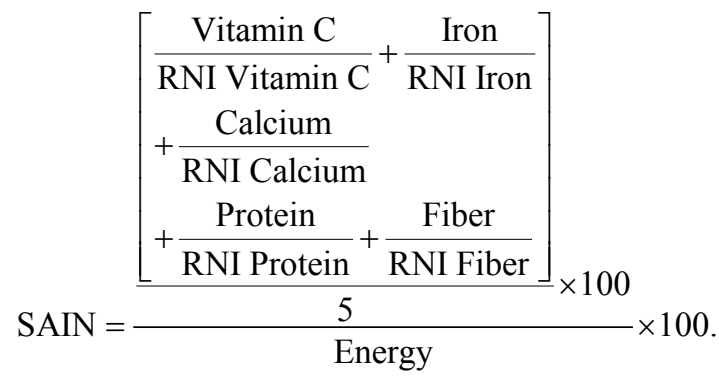

RNI (Recommended nutritional intake)

The LIM calculation formula is as follows:

$$
\mathbf{L I M}=\frac{\frac{\mathbf{N a}}{3153}+\frac{\mathbf{S F A}}{22}+\frac{\text { Added sugar }}{50}}{3} \times 100
$$

$\mathrm{SFA}=$ Saturated fatty acid

These two values plotted on a graph used to classify foods into four groups. It considers two acceptability thresholds (SAIN $>5$ and LIM $<7.5$ ):

1. Foods recommended for health $(\mathrm{SAIN}>5$ and LIM $<7.5)$

2. Neutral foods (SAIN $<5$ and LIM $<7.5$ )

3. Foods recommended in small quantities or occasionally (SAIN $>5$ and LIM $>7.5)$

4. Foods to limit (SAIN $<5$ and LIM $>7.5)$.

\subsubsection{Statistical Analysis}

Results made in triplicate measurements were expressed as means with standard deviation with statistica 7.1. Graphical representations were made with Microsoft Word and Microsoft Excel.

\section{Results}

\subsection{Biochemical Composition of the Saba senegalensis Pulp}

\subsection{1. pH, Titratable Acidity, Ashes and Dry Matters}

The $\mathrm{pH}$ and titratable acidity value, ash (\%) and the dry matters $(\%)$ contents of the Saba pulp are represented in Figure 2. Results showed that Saba senegalensis pulp has a low value of $\mathrm{pH}(3.03 \pm 0.01)$ and titratable acidity $(0.28 \pm 0.01 \%)$. It also contains $0.46 \pm 0.01 \%$ of ash and $13.26 \pm 0.81 \%$ of dry matter.

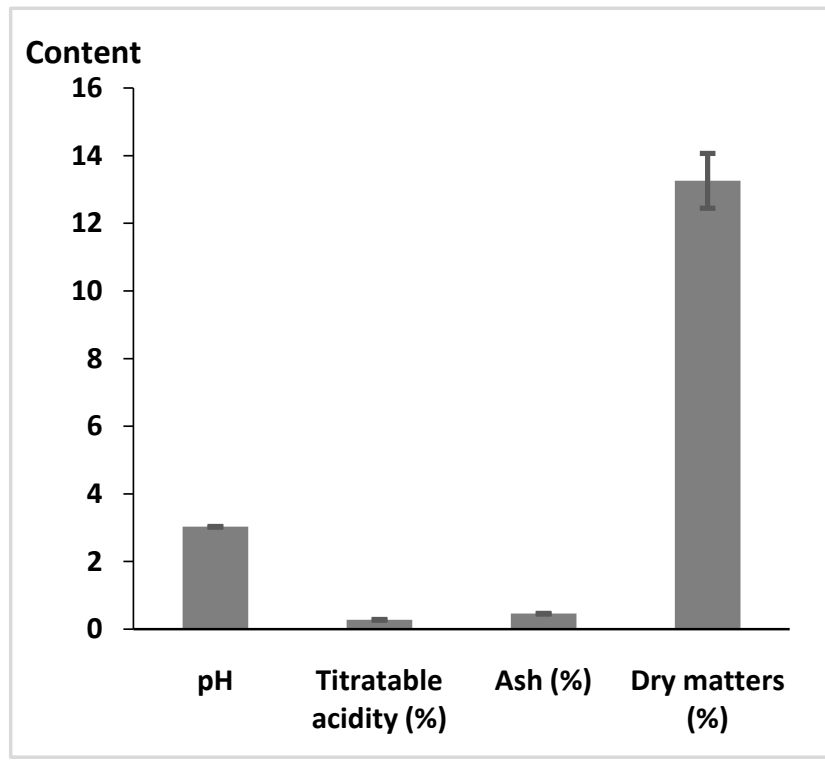

Figure 2. pH, titrable acidity, dry matters and ashes

\subsubsection{Macronutrients Content}

The composition in macronutrients of the Saba pulp is presented in Figure 3. Results showed the low content of 
protein, lipid and reducer sugar respectively (2.91 \pm $0.51 \%),(1.48 \pm 0.21 \%)$ and $(2.03 \pm 0.08 \%)$. On the other hand, total carbohydrates and total sugars content were higher with respective values of $8.42 \pm 0.74 \%$ and $6.13 \pm 0.12 \%$.

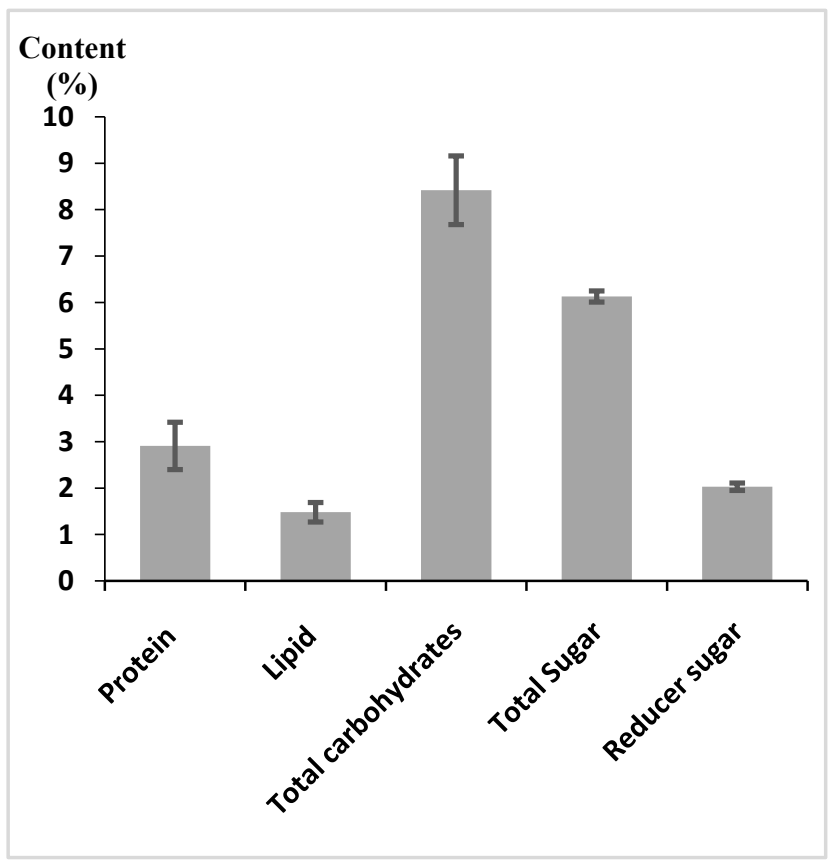

Figure 3. Macronutrients contents

\subsubsection{Minerals, Vitamin $\mathrm{C}$, $\boldsymbol{\beta}$-carotene and Fibbers Content}

The minerals, vitamin $\mathrm{C}, \quad \beta$-carotene and fibbers contents of the Saba pulp are represented in Table 1. The results showed that Saba pulp is rich in minerals content. This pulp has a high percentage of potassium (116.96 \pm $2.06 \mathrm{mg} / 100 \mathrm{~g})$, a considerable quantity in calcium (36.61 $\pm 2.79 \mathrm{mg} / 100 \mathrm{~g})$. Nevertheless, it is weak in zinc $(0.38 \pm$ $0.11 \mathrm{mg} / 100 \mathrm{~g})$ and in iron $(1.04 \pm 0.65 \mathrm{mg} / 100 \mathrm{~g})$. The results showed that Saba pulp is rich in vitamin $C$ and $\beta$-carotene with respective contents of $36.67 \pm 2.22 \mathrm{mg} / 100 \mathrm{~g}$ and $189.62 \pm 1.33 \mu \mathrm{g} / 100 \mathrm{~g}$. Concerning the fibbers, Saba pulp contains a low fibbers content of $0.20 \pm 0.02 \%$.

Table 1. Minerals, vitamin C, $\beta$-carotene, fibbers contents

\begin{tabular}{|l|l|}
\hline Chemical parameters & Contents \\
\hline Minerals (mg/100g) & Contents \\
\hline Sodium $(\mathrm{Na})$ & $4.43 \pm 0.78$ \\
\hline Magnesium $(\mathrm{Mg})$ & $14.18 \pm 1.48$ \\
\hline Phosphorus $(\mathrm{P})$ & $17.86 \pm 0.41$ \\
\hline Potassium $(\mathrm{K})$ & $116.96 \pm 2.06$ \\
\hline Calcium $(\mathrm{Ca})$ & $36.61 \pm 2.79$ \\
\hline Iron $(\mathrm{Fe})$ & $1,04 \pm 0.65$ \\
\hline Zinc $(\mathrm{Zn})$ & $0.38 \pm 0.11$ \\
\hline Silicon $(\mathrm{Si})$ & $1.62 \pm 0.23$ \\
\hline & \\
\hline Vitamin and Fibbers & Contents \\
\hline Vitamin C $(\mathrm{mg} / 100 \mathrm{~g})$ & $36.67 \pm 2.22$ \\
\hline$\beta$-carotene $(\mu \mathrm{g} / 100 \mathrm{mg})$ & $189.62 \pm 1.33$ \\
\hline Fibbers $(\%)$ & $1.52 \pm 0.06$ \\
\hline
\end{tabular}

\subsubsection{Phytonutrients and Antinutritionals Factors}

The phytonutrients content and antinutritionals factors content are showed in Table 2. The results showed the high content of oxalic acid, total phenols and tannins with respective values of $381.33 \pm 12.67 \mathrm{mg} / 100 \mathrm{~g}$, $264.76 \pm 4.54 \mathrm{mg} / 100 \mathrm{~g}$ and $198.94 \pm 1.19 \mathrm{mg} / 100 \mathrm{~g}$. As for as the contents of flavonoids and phytates, results showed the low values respectively of $53.44 \pm 1.16 \mathrm{mg} / 100 \mathrm{~g}$ and $31.18 \pm 0.13 \mathrm{mg} / 100 \mathrm{~g}$.

Table 2. Phytonutriments and antinutritionals factors Contents

\begin{tabular}{|l|l|}
\hline & Contents $(\mathbf{m g} / \mathbf{1 0 0 g})$ \\
\hline Phytonutrients & \\
\hline Total phenolic & $264.76 \pm 4.54$ \\
\hline Flavonoids & $53.44 \pm 1.16$ \\
\hline Antinutritional Factors & \\
\hline Phytates & $31.18 \pm 0.13$ \\
\hline Oxalic Acid & $381.33 \pm 12.67$ \\
\hline Tannins & $198.94 \pm 1.19$ \\
\hline
\end{tabular}

\subsubsection{SAIN and LIM Score of Saba}

Figure 4 shows the SAIN and LIM score of the Saba pulp. The SAIN score of the pulp was 18.85 and LIM score was 2.29. Results showed that Saba senegalensis pulp have a good nutritional profile because their SAIN were higher than 5 and LIM were lower than 7.5. The different SAIN and LIM scores obtained show that Saba senegalensis pulp studied belongs to Group 1 foods. This group contains foods recommended for health.

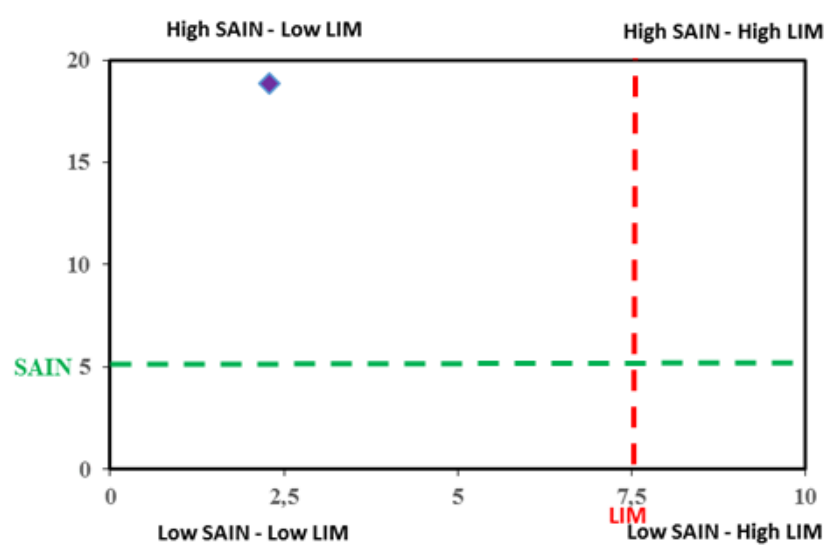

Figure 4. SAIN and LIM Scores of Saba pulp

\section{Discussion}

The objective of this study was to evaluate the nutritional potential of Saba senegalensis pulp for better valorization. The $\mathrm{pH}$ value helps to determine the state of deterioration of the fruit and is therefore associated with its quality and safety. In this result, the low $\mathrm{pH}$ value obtained (3.03) showed that the S.senegalensis pulp is acid and it will be able to resist of microbial activities, especially the pathogenic germs and could be conserved for long time. These results were accordance with those obtained by [22] in similar fruits such as passion (2.77) and the mango (3.90). The previous studies carried out by 
[23] reported that $\mathrm{pH}$ between 2.5 and 5.5 prevents the multiplication of micro-organisms and involves a long conservation of the fresh fruit. Like $\mathrm{pH}$, titratable acidity is also very important for the determination of the pulp fruit quality. Titratable acidity is related to the sour taste of food and expresses the quantity of organic acids. The low titratable acidity value obtained in these results could be explained by the organic acids content in Saba pulp. According to [24], the organic acids contents have the capacity to reduce the $\mathrm{pH}$ and the growth of certain bacteria pathogenic. Due to the low $\mathrm{pH}$ and low acid titratable values obtained in this result, S. senegalensis pulp could be used as food preservative.

The moisture content in S.senegalensis pulp was relatively high $(86.73 \pm 0.46 \%)$. This value vas higher than those obtained by [7] in Saba comorensis pulp (74.08 $\pm 0.15 \%)$, mango $(83.11 \pm 0.85 \%)$, and passion juice $(82.1 \pm 0.85 \%)$, but lower than those obtained in orange juice $(87.1 \pm 0.15 \%)$. Moisture determination is one of the most important and the most measurements used in processing and testing of food. Moisture content is importance to both the stability and quality of foods. According to [25], the moisture of the pulpy fruits is about 80 to $90 \%$.

Concerning the composition of macronutrients of Saba senegalensis (S.senegalensis) pulp, the results showed the low content of crude proteins $(2.91 \pm 0.51 \%)$. Most fruit pulps often contain less protein. This low protein content was comparable with those obtained by [26] in the juice of baobab leaves (Adansonia digitata L.) which varies between $1.80 \%$ and $2.60 \%$, but higher than that obtained by [27] in pineapple juice (Ananas comosus L.) $(0.54 \%)$. Due to the low protein content, S.senegalensis like the other fruit could not be excellent source of protein.

Fat content is known to provide high energy content and can be reservoir of fat-soluble vitamins.

According to [28], food with low fat content is good for obese patients as they don't require high levels of carbohydrates. In this study, the lipid content obtained $(1.48 \%)$ is lower than those obtained by $[29,30]$ in the pulp of Saba $(8.92 \%)$, but higher than that of the table of composition of food in West Africa $(0.2 \pm 0.1 \%)$. The difference of fat content obtained in this result and those of the literature could be explained either by the different varieties studied, or by the nature of solvent and the extraction method used. The pulp of S.senegalensis has a low content of energy $\approx 58.64 \mathrm{kcal}$. This low content of energy can be explained by the low contents of macronutrients in $S$. senegalensis pulp. Considering its low energy value, Saba senegalensis fruit could be recommended to the obese and diabetic patients or in overweight.

The carbohydrates content obtained in this result $(8.42 \pm 0.74 \%)$ was lower than those of by [28] in the Saba pulp (14.23\%). In addition, the carbohydrates content obtained was lower than those available in the composition table of food of West Africa which is $17.1 \%$. The difference of these results could be explained either by the various varieties used, or by the various extraction and dosage methods. The studies carried out by [31] have showed that sugar contents vary according to the climate, the stage of maturation, the exposure to the sun, the availability of water and the content of minerals of the soils. The total sugar contents of S.senegalensis pulp $(6.13 \%)$ were in agreement with those of wild fruits such as Ziziphus mauritiana Lamk. varying from 5.4 to $10.5 \%$ [32]. In this study, the low reducer sugar content of $S$. senegalensis is comparable to those of oranges and tangerines which varies between 2 and 4\% [33]. These values were lower than those obtained by [34] on cashews (7.8\%). Taking into the contents obtained in this study, S.senegalensis would constitute a considerable source of sugars which provide calories, and confer on the fruits their sweet savors.

The ash content represents the total quantity of minerals present in food. The ash content in S.senegalensis was $0.46 \pm 0.01 \%$. This value was in agreement with that reported in the table of composition of food in West Africa which is $0.40 \%$ [35]. Studies carried out by [36] showed that the micronutrients do not provide calories but they play a significant role in the metabolic processes of the organism. The results showed that the pulp of Saba senegalensis is an excellent source of minerals compared to other consumed fruits. Among these minerals, potassium is present in high quantity (116.96 \pm 2.06 $\mathrm{mg} / 100 \mathrm{~g})$. This result is comparable with that of [37] which showed that potassium is the most abundant mineral in the pulp of baobab. In this result, the $\mathrm{K} / \mathrm{Na}$ ratio was 26.40 . This ratio is higher than that recommended by [38] which is 5.0. The $\mathrm{K} / \mathrm{Na}$ ratio is a significant parameter in the nutritional evaluation of food especially for the persons suffering from hypertension. Due to the high content of potassium and its availability in Saba senegalensis pulp, the consumption of this fruit could help to fill the daily nutritional requirement in potassium and to avoid disfonctionnements of the human organism. Saba senegalensis is a significant source of calcium (36.61 \pm $2.79 \mathrm{mg} / 100 \mathrm{~g}$ ). This result is higher than that reported by [39] on the orange fruits $(25.50 \pm 1.90)$. Saba senegalensis fruit contained a low amount of crude fibber $(1.52 \pm$ $0.06 \%$ ) as compared to that of the table of composition of food in West Africa which is 1.30. This result is lower than that reported by [28] on Saba fruit which is $13.52 \%$. This difference could be explained by various conditions: geographical localization, the genetic constitution, the state of the ground, climatic conditions and the methods of culture and analysis. The pulp of $S$. senegalensis is also rich in vitamin $A(\beta$-carotene $\approx 189.62 \pm 1.33 \mu \mathrm{g} / 100 \mathrm{~g})$ and vitamin $C$. The $\beta$ - carotene reported in this study is much lower than that of Saba senegalensis juice $(1559 \mu \mathrm{g} / 100 \mathrm{~g})$ as has been reported by [4], but higher than that reported in the West African food composition table (traces). B-carotene is converted into retinol (vitamin A) in the human organism with a better yield estimated at 1/6 [40]. Vitamin A intervenes in growth, vision, and resistance to infection. Its deficiency is a major contributor to infant-juvenile mortality [41]. Due to the high vitamin content, Saba pulp could be a promising choice to increase dietary intake of carotenoids. Moreover, the consumption of this pulp could be beneficial for health considering the protective role and the antioxidant capacity of the vitamin $\mathrm{C}$ that it contains.

Like the composition in macro and micronutrients, Saba senegalensis pulp contains also phytonutrients which play the role of antioxidants. Saba pulp has a total phenol content of $264.76 \pm 4.54 \mathrm{mg} / 100 \mathrm{~g}$. This content is higher 
than that of Safou (100 mg / 100g) obtained by [42]. The flavonoids content in this result $(53.44 \pm 1.16 \mathrm{mg} / 100 \mathrm{~g})$, is higher than that of the apple $(37.27 \mathrm{mg} / 100 \mathrm{~g})$ obtained by [43]. The high levels of total phenols of Saba pulp could explain its astringency which would limit its consumption. This result also showed the high content of tannin (198.94 $\pm 1.19 \mathrm{mg} / 100 \mathrm{~g})$. Antioxidant compounds in food play an important role as health protecting factor. Scientific evidence suggests that antioxidants reduce the risk of chronic diseases including cancer and heart disease. The fact that S.senegalensis pulp contains the high content of antioxidants such as tannins and flavonoids, the consumption of this fruit in sufficient amount could provide nutrients and adequate protection against diseases.

The results showed that Saba pulp contains antinutritional factors such as phytates $(31.18 \pm 0.01 \mathrm{mg} / 100 \mathrm{~g})$ and oxalic acids $(381.33 \pm 12.67)$. The phytate content obtained in this result was lower than that of baobab pulp (200 mg / $100 \mathrm{~g}$ ) reported by [44]. Phytates have the characteristic to chelate the minerals by generating insoluble molecular complexes with divalent cations such as $\mathrm{Ca}_{2}{ }^{+}, \mathrm{Fe}_{2}{ }^{+}, \mathrm{Zn}_{2}{ }^{+}$or $\mathrm{Mg}_{2}^{+}$, which can modify their bioavailability and decrease their absorption. The high content of oxalate $(381.33 \pm 12.67 \mathrm{mg} / 100 \mathrm{~g})$ in this result could be cause the irritation in the mouth and interferes with the absorption of minerals especially bivalent calcium.

As far as the nutritional profile, results showed that Saba senegalensis pulps have a good nutritional profile because their score SAIN is higher than 5 and their score LIM is lower than 7.5. These score SAIN and LIM have classified $S$. senegalensis in the group 1 food. This group contains foods recommended for health. The use of the SAIN and LIM system help to choose the best food for children and also help to reduce malnutrition. These results were in accordance with those obtained by [45]. These authors demonstrated that beans and peas have LIM scores below 7.5 and SAIN scores above 5. Beans and peas belong to the group of foods recommended for health. Results obtained in S.senegalensis pulp were in accordance with those obtained by $[46,47,48]$. These authors in previous studies are demonstrated that the group 1 foods are characterized by the low-calorie, but rich in mineral, and vitamin.

\section{Conclusion}

This study determined the biochemical composition and nutritional potential of Saba senegalensis fruit. The results were showed that the pulp has a low content of proteins, but high content of vitamin $\mathrm{C}, \beta$-carotene and minerals. The nutritional profile of Saba senegalensis pulp has shown that this fruit is healthy food for consumption. So it can be recommended for the health and growth of children. The results suggested that the consumption of the fruit in sufficient amount could provide nutrients and adequate protection against diseases. In the same way, the implementation techniques for valorization of the pulp and juice will make it possible to reach a wider public and will make this resource available out of season.

\section{Statement of Competing Interests}

The authors have no competing interest in relation to their work.

\section{List of Abbreviations}

RNI: Recommended nutritional intake

SAIN: Favorable aspects of the food

LIM: Adverse aspects of the food

h: Hour

$\mathrm{pH}$ : potentiel hydrogène

g: gram

\section{Acknowledgements}

Authors would like to thank all the farmers for their generosity, technical assistance and documentation. Their also thank the Nutrition and Technology teams of the Nangui Abrogoua University, the Peleforo Gon Coulibaly University and the National Polytechnic Institute Houphouet Boigny (INP-HB) for their contribution in this study.

\section{References}

[1] Angaman D. M., Barima Y. S. S., Seguena F., Kouassi A. F., \& Soro K. Les plantes alimentaires vendues sur les marchés d'Abidjan. Thèse de l'Université de Cocody, Abidjan, Côte d'Ivoire.189p, 2001.

[2] Cook J.A., VanderJagt D.J., Pastuszyn A., Mounkaila G., Glew R.S., Milson M., \& Glew R.H., Nutrient and chemical composition of 13 wild plant foods of Niger, Journal of Food Composition and Analysis 13: 83-92, 2000.

[3] Ambé G.A., \& Malaisse F., How Ivory Coast's Malinké ethnic group select the most beneficial wild fruits, Agroforestry Today 13 1-44, 2002.

[4] Kini F., Saba A., Ouedraogo S., Tingueri B., Sanou G., \& Guissou I.P., Potentiel nutritionnel et thérapeutique de quelques espèces fruitières "sauvages " du Burkina Faso, Pharmacopée et Médecine Traditionnelle Africaines 15 : 32-35, 2008.

[5] Yougbaré-Ziébrou M.N., Ouédraogo N., Lompo M., Bationo H., Yaro B., \& Gnoula C., Anti-inflammatory, analgesic and antioxidant activities of an aqueous extract of Saba senegalensis Pichon stems with leaves (Apocynaceae), Phytothérapie. 2015.

[6] Sarr S.O., Fall A.D., Gueye R., Diop A., Sene B., Diatta K., NDiaye B., \& Diop Y.M., Evaluation de l'activité antioxydante des extraits des feuilles d'Aphania senegalensis (Sapindaceae) et de Saba senegalensis (Apocynaceae). International Journal Biology Chemist Scientific 9(6): 2676-2684, 2015.

[7] Omujal F., Bigirimana C., Isubikalu P., Malinga M., Bizuru E., Namutebi A., Obaa B.B., Agea J.G., \& Okullo J.B.L., Morphological and Physico-Chemical Characteristics of Saba comorensis: A Highly Preferred Lake Victoria Basin Indigenous Fruit Tree in Busia District, Eastern Uganda. Journal of Medicinal Plants Studies Vol. 2 Issue. 2, pp 127-136., 2014.

[8] James O., Rotimi A.A., \& Bamaiyi B.O.J., Phytoconstituents, proximate and nutrient investigations of Saba florida (Benth.) from Ibaji forest. International Journal of Nutrition and Metabolism Vol. 2, issue 5, pp. 88-92, 2010.

[9] Attah A.F., O'Brien M., Koehbach J., Onibare M.A., Moody J.O., \& Smith TJ., Uterine contractility of plants used to facilitate childbirth in Nigerian ethnomedicine. Journal of Ethnopharmacology 143(1): 377-382, 2012.

[10] Aké Assi L., \& Guinko S. Plantes utilisées dans la médecine traditionnelle en Afrique de l'Ouest. Edition Roche, Genève. 151 p., 1991. 
[11] Koné M. W., Atindehou K. K., Téré H., \& Traoré D., Quelques plantes médicinales utilisées en pédiatrie traditionnelle dans la région de Ferkessédougou (Côte-d'Ivoire). Bioterre, Revue Internationale Sciences de la Vie et de la Terre Numéro spécial : 30-36, 2002.

[12] Le Coque R., Bureau interprofessionnel d'Etudes Analytiques. Recueil de méthodes d'analyses des communautés Européennes, 1965.

[13] A.O.A.C. Official Methods of Analysis.Washington D.C. 15th edn, pp: 375-379, 1990.

[14] BIPEA, Bureau Inter Professionnel d'Etude Analytique. Recueil des Méthodes d'Analyse des communautés européennes 110p, 1976.

[15] A.O.A.C. Official Methods of Analysis.Washington D.C. 15th edn, pp: $375-379,1995$.

[16] Pelletier O., Smoking and vitamin C levels in humans. American Journal Clinical Nutritional 21:1259-1267, 1968.

[17] Scalbert A., Monties B., \& Janin G., Tannins in wood: comparison of different estimation methods. J Agric Food Chem 37: 1324$1329,1989$.

[18] Meda A., Lamien C.E., Romito M., Millogo J., \& Nacoulma O.G., Determination of the total phenolic, flavonoid and proline contents in Burkina Faso honey, as well as their radical scavenging activity. Food Chemistry, 91: 571-577, 2005.

[19] Mohammed A.I., Ponnamperuma A.J.P., \& Youssep S.H., New chromophore method for phytic acid determination? Cereal Chemistry, 63(6): 475-478, 1986.

[20] Bainbridge Z., Tomlins K., Wellings K., \& Westby A., Methods for assessing quality characteristics of non-grains starch staples (Part 3. Laboratory methods). Chatham, UK: Natural Resources Institute, 83: 185-193, 1996.

[21] Darmon N., Briend A., \& Drewnowski A., Energy-dense diets are associated with lower diet costs: A community study of French adults. Public Health Nutr., 7(1), pp. 21-27, 2004.

[22] Appiah F., Kumah P., \& Idun I. Effect of ripening stage on composition, sensor qualities and acceptability of Keitt mango (Mangifera indica L.) CHIPS. Africa Journal of Food Agriculture nutrition and Development; 11(5):5096-5109, 2011.

[23] Gbago Onivogui, Huaiyuan Zhang, Erasto Mlyuka, Mohamed Diaby, \& Yuanda Song, Chemical Composition, Nutritional Properties and Antioxidant Activity of Monkey Apple (Anisophyllea laurina R. Br. ex Sabine). Journal of Food and Nutrition Research, Vol. 2, No. 6, 281-287, 2014.

[24] Vondruskova H., Slamova R., Trckova M., Zraly Z., \& Pavlik I., Alternatives to antibiotic growth promoters in prevention of diarrhoea in weaned piglets: a review. Veterinari Medicina 55(5): 199-224, 2010.

[25] Bretaudeau J., \& Fauré Y., Atlas d'arboriculture fruitière. Ed .Tec et Doc. Paris. 289p, 1992.

[26] Diop A.G., Sakho M., Dornier M., Reynes M., Mar Diop C.G., \& Sock O., Fruit du baobab : étude de la transformation de la pulpe en nectar. Maîtrise des Procédés en vue d'améliorer la qualité et la sécurité des aliments, Utilisation des OGM, Analyse des risques en agroalimentaire. Ouagadougou, 8-11 Novembre 2005.

[27] Hossain M.d., Farid S.A., \& Mustafa A., Nutritional value and medicinal benefits of Pineapple. International Journal of Nutrition and Food Sciences 4(1): 84-88, 2015.

[28] Ayessou N.C., Gueye M., Dioh E., Konteye M., Cissé M., \& Dornier M., Composition nutritionnelle et apport énergétique du fruit de Maerua pseudopetalosa, aliment de soudure au Sénégal. Fruits; 64:147-156, 2009

[29] Boamponsem G.A., Johnson F.S., Mahunu G.K., \& Awiniboya S. F., Determination of biochemical composition of Saba senegalensis (Saba fruit). Asian Journal of Plant Science and
Research 3(1): 31-36, 2013.

[30] Gaouar N., Etude de la valeur nutritive de la caroube de différentes variétés Algériennes. Thèse de magistère en Nutrition. Université Abou Bakr Belkaid. Tlemcen, 95p., 2011.

[31] Doukani K., \& Tabak S., Profil Physicochimique du fruit "Lendj" (Arbutus unedo L.). Revue «Nature \& Technologie». B-Sciences Agronomiques et Biologiques, $\mathrm{n}^{\circ} 12$, 53-66pp, 2014.

[32] Pareek S., Nutritional composition of jujube fruit. Emir. J. Food Agric. 25 (6): 463-470, 2013.

[33] Hui Y. H., Barta J., \& Cano P., Handbook of Fruits and Fruit Processing. Wiley, 697 p, 2008.

[34] Lautié E., Dorniera M., De Souza F.M., \& Reynesa M., Les produits de l'anacardier : caractéristiques, voies de valorisation et marchés. Fruits 56: 235-248, 2001.

[35] Stadlmayr B., Charrondiere U.R., Enujiugha V.N., Bayili R.G., Fagbohoun E.G., Samb B., Addy P., Barikmo I., Ouattara F., Oshaug O., Akinyele I., Amponsah A.G., Bomfeh K., Ene-Obong H., Smith I.F., Thiam I., \& Burlingame. B., Table de composition des aliments d'Afrique de l'Ouest. Food and Agriculture Organization of the United Nations Rome 2012.

[36] Ismail F.M.R., Anjum A.N., Mamon., \& Kazi T.G., Trace metal contents of vegetables and fruits of Hyderabad retail market. Pak. J. Nutr., 10: 365-372, 2011

[37] Cissé I., Caractérisation des propriétés biochimiques et nutritionnelles de la pulpe de baobab des espèces endémiques de Madagascar et d'Afrique continentale en vue de leur valorisation. Rapport de thèse, Génie des procédés, Montpellier SUPAGRO, 167 p., 2012.

[38] Szentmihalyi K., Kery A., Then M., Lakatos B., Sandor Z., \& Vinkler P., Potassium-sodium ratio for the characterization of medicinal plant extracts with diuretic activity. Phytotherapy Res. 12: 163-166, 1998.

[39] Dipak P.K., \& Ranajit K.S., Nutrients, vitamins and minerals content in common citrus fruits in the Northern Region of Bangladesh. Pakistan Journal of Biological Sciences 7: 238-242, 2004.

[40] Favier J.C., Ireland-Ripert J., Laussucq C., \& Feinberq M., Répertoire général des aliments $\mathrm{T} 3$ : table de composition des fruits exotiques, fruits de cueillette d'Afrique. p 55. Techniques et documentation, 1993.

[41] Tee E.S., Carotenoids and retinoids in human nutrition; Critical Review in Food Science and Nutrition 31: 63-103, 1992.

[42] Missang C.E., Guyot S., Renard M.G.C., Baron A., \& Drilleau J.F., Les polyphénols du safou (Dacryodes edulis (G. Don) H.J. Lam) et leur évolution au cours de la maturation, 2008.

[43] Lotito S.B., \& Frei B., The increase in human plasma antioxidant capacity after apple consumption is due to the metabolic effect of fructose on urate, not apple-derived antioxidant flavonoids. Free Radic Biol Med 37 (2), 251-8, 2004.

[44] Nkafamiya I.I., Osemeahon S.A., Dahiru D., \& Umaru H.A., Studies on the chemical composition and physicochemical properties of the seeds of baobab (Adansonia digitata). African Journal of Biotechnology 6 (6), 756-759, 2007.

[45] Koné M.B., Traoré S., \& Brou K., Use of SAIN and LIM System for Determination of Nutritional Profile of Foods Consumed by Under-five Children in the District of Abidjan. Ivory Coast. Global journal of biology. Agriculture \& Health Sciens. 5 (1):1-6, 2016.

[46] Roman, Farell., \& Maxwel, Benefits of fruits and vegetables for health. Crosspub, 120p, 2005.

[47] Darmon N., Recommendations for a balanced diet. Diet info. 16 (4), pp. 26-31, 2007

[48] Masset T. Impact of consumption of fruit and vegetable on human health. Dario Eds. 243p, 2009. 